\title{
RAMUAN “PUREE” SEBAGAI ALTERNATIF SUBTITUSI ROKOK; STUDI FENOMENOLOGI KEARIFAN LOKAL MASYARAKAT ANGATA, KONAWE SELATAN
}

\author{
Fikki Prasetya ${ }^{1}$ \\ ${ }^{1}$ Promosi Kesehatan, FKM Universitas Halu Oleo \\ ${ }^{1}$ Fikki.prasetya@uho.ac.id
}

\begin{abstract}
Abstrak
"Puree" adalah ramuan lokal yang memiliki reputasi sebagai pengganti rokok oleh masyarakat angata, dan telah digunakan secara turun-temurun sebagai warisan budaya dari leluhur mereka, serta belum ditemukan penggunaannya di tempat lain. Puree adalah ramuan yang dibuat dari campuran air tembakau dan kapur sirih yang di satukan membentuk semacam pasta and digunakan dengan cara dioles pada bibir pengguna. Tujuan dari penelitian ini adalah untuk menganalisis fenomena ramuan tradisional bernama "Puree" sebagai pengganti rokok pada upaya berhenti merokok pengguna. Metode penelitian ini adalah metode kualitatif dengan menggunakan studi fenomenologi serta melibatkan 10 informan. Pengumpulan data dilakukan melalui wawancara dan observasi semi-terstruktur menggunakan rekaman data, protokol wawancara, dan catatan lapangan. Analisis konten digunakan untuk menganalisis data. Hasil penelitian menunjukkan dalam empat interpretasi utama tentang ramuan "Puree" yaitu: menggantikan rokok dalam upaya penghentian merokok dengan dampak yang lebih memuaskan dan terasa lebih positif, bahan baku di produksi skala lokal sehingga mudah tersedia dan lebih murah, rokok menjadi kurang diinginkan bagi pengguna aktif Puree dan relatif dianggap aman, dan tingkat ketergantungan/kecanduan dirasakan lebih rendah dari merokok. Kesimpulan yang dapat ditarik adalah Warga Angata mendukung penggunaan Puree sebagai terapi penghentian merokok untuk perokok dewasa. Pada umumnya masyarakat ngata memanfaatkan ramuan ini dengan salah satu motif untuk berhenti merokok, meskipun ditemukan ada beberapa motif lain penggunaan puree. Belum diketahui efek karsinogenik dari penggunaan Puree, sehingga memerlukan penyelidikan lebih lanjut.
\end{abstract}

Keywords : Kearifan Lokal, Ramuan "Puree", Pengganti Rokok, Upaya Berhenti Merokok

\begin{abstract}
"Puree" is a local mixture that have reputation as smoking substitute by residensts in angata, and has been used for generations as a cultural heritage from their ancestors, and no one has been found used elsewhere before. Puree is a mixture made from a mixture of tobacco water and whiting which is combined to form a kind of paste and is used by applying it to the user's lips. The aim of this study is to analyze the phenomenon of the traditional mixture named "Puree" as a substitute for cigarettes during smoking cessation. Qualitative method used phenomenology study involving 10 Informants. Data were collected through semi-structured indepht interview and observations using data recording, interview protocol, and field note. Content analisys was used to analyse data. The Results showed into four main interpretations of "Puree" there are: substitute a more satisfactory to smoking cessation with a more positive impact, local produce raw materials are easily available and cheap, cigarettes become less desirable for active users Puree and relatively considered safe, and the level of dependency / addiction lower than smoking. The Conclussions that can be drawn are the Residents of Angata supports the use of Puree as smoking cessation therapy for adult smokers. They are involved with this product with a pattern of quitting smoking, although it is found that there are several other motives for the use of puree. There is no known carcinogenic effect from using Puree, so it requires further investigation.
\end{abstract}

Keywords : Local Wisdom, "Puree" Mixture, Smoking Subtitution, Smoking Cesation 


\section{PENDAHULUAN}

Merokok masih menjadi salah satu masalah dalam kesehatan masyarakat. Masih tingginya jumlah perokok menyumbang faktor resiko penyakit mematikan seperti Penyakit Kardiovaskuler dan penyakit kronik lainnya ${ }^{1}$.

Di Indonesia, rerata proporsi perokok umur 10 tahun ke atas adalah 29,3\%. Perilaku merokok penduduk dengan umur 15 tahun ke atas masih belum mengalami penurunan dari tahun 2007 hingga 2013, justru cenderung meningkat dari $34,2 \%$ tahun 2007 menjadi 36,3\% tahun 2013. Laki-laki $64,9 \%$ dan perempuan 2,1\% masih menghisap rokok. Dibandingkan dengan penelitian Global Adults Tobacco Survey (GATS) pada penduduk kelompok umur 15 tahun ke atas, proporsi perokok laki- laki $67 \%$ dan pada Riskesdas 2013 sebesar 64,9\%, sedangkan pada perempuan menurut GATS adalah 2,7\% dan menurut Riskesdas 2013 adalah 2,1\%. Dari perbandingan tersebut dapat dilihat bahwa proporsi perokok laki-laki lebih tinggi daripada perempuan ${ }^{2}$.

Di Sulawesi Tenggara sendiri, populasi perokok aktif sebesar 21,8 persen dari jumlah penduduknya [3] ${ }^{3}$. Data ini menggambarkan begitu tingginya populasi perokok aktif yang ada di Indonesia, khususnya di Sulawesi Tenggara. Data-data hasil riset tersebut menunjukkan bahwa jumlah penggunaan rokok semakin meningkat, padahal sudah menjadi pengetahuan bersama bahwa merokok menjadi faktor risiko terjangkitnya penyakit kronis, seperti kanker, penyakit paru-paru dan penyakit kardiovaskuler ${ }^{4}$.

Rokok terus membunuh hampir 6 juta orang setiap tahun. Lebih dari 600.000 perokok pasif juga meninggal karena paparan asap rokok. Jika kecenderungan ini terus berlanjut, pada tahun 2030 diperkirakan rokok akan membunuh lebih dari 8 juta orang di seluruh dunia setiap tahun hingga setengah dari 1 miliar perokok di dunia pada akhirnya akan mati karena penyakit terkait dengan rokok. ${ }^{4}$

Saat ini kekhawatiran akan dampak merokok sudah menjadi perhatian. Tingginya kasus kejadian penyakit akibat merokok memicu sebagian masyarakat untuk mencoba mencari cara untuk menghentikan kebiasaan merokok. Hasil penelitian Firzawati ${ }^{5}$, menemukan bahwa upaya berhenti merokok dipengaruhi oleh faktor berupa mendapatkan nasehat untuk berhenti merokok, melihat peringatan kesehatan, dan mendapatkan informasi bahaya merokok.

Di antara seluruh perokok, 70\% ingin berhenti merokok dan 46\% perokok berusaha berhenti merokok tiap tahunnya $[10]^{6}$. Namun hanya $1-3 \%$ yang berhasil berhenti spontan (tanpa bantuan tenaga kesehatan). Nasihat sederhana dari tenaga kesehatan dapat meningkatkan angka keberhasilan menjadi $3 \%$. Bantuan program intervensi yang minimal dapat meningkatkan angka keberhasilan menjadi $5-10 \%$ dan terapi yang lebih intensif, termasuk klinik berhenti merokok, dapat meningkatkan angka keberhasilan hingga 25-30\%. Karena itulah kalangan kesehatan mengembangkan berbagai usaha untuk menghentikan kebiasaan merokok $^{6}$.

Banyak perokok telah mencoba obat yang dijual bebas untuk menghentikan kebiasaan merokok sebelum berdiskusi dengan petugas kesehatan. Penggunaan obat bebas terkadang tidak memuaskan karena pemilihan dan penggunaan yang kurang tepat ${ }^{3}$. Berbagai faktor juga turut mempengaruhi hasil usaha menghentikan kebiasaan merokok seperti kontak dengan orang-orang yang masih merokok atau keadaan lain yang dapat menimbulkan relapsnya kebiasaan merokok $^{6}$.

Penggunaan tembakau tanpa asap sudah sering dijumpai dalam masyarakat, seperti tembakau kunyah. Di Eropa Tengah dan Timur tingginya penggunaan nikotin tanpa asap terdapat pada produk permen karet nikotin, serta semprotan nikotin, yang terdaftar sebagai produk farmasi merupakan alternatif murah dan ekonomis. Tembakau dengan kadar nitrosamine rendah, yang secara kinetis nikotin lebih mirip dengan merokok, menawarkan kemungkinan lain untuk terapi pengganti nikotin untuk berhenti merokok ${ }^{7}$.

Sitepoe $^{8}$ menguraikan bentuk dan olahan daun tembakau yang di konsumsi oleh masyarakat Indonesia, diantaranya yaitu: Pemakaian tembakau tanpa asap (Smokeless Tobacco) dan Pemakaian tembakau sebagai rokok.

Salah satu upaya menghentikan kebiasaan merokok yang juga merupakan warisan turun temurun ditemukan pada warga Kecamatan Angata Kabupaten Konawe Selatan, Indonesia. Warga Angata menggunakan ramuan tradisional yang disebut "Puree" sebagai salah satu kearifan lokal warga setempat sebagai alternatif bagi warga mereka yang berkeinginan berhenti merokok. Puree merupakan ramuan yang bahannya merupakan campuran dari tembakau, kapur sirih dan sedikit air.

Dalam tulisan ini, kami menggali fenomena terkait pemanfaatan ramuan tradisional Puree dan mencoba melihat efektifitasnya sebagai ramuan yang digunakan dalam upaya untuk menghentikan kebiasaan merokok. Salah satu ke khasan dari produk ramuan ini tidak hanya menghirup tembakau tapi bahan lainnya berupa kapur sirih 
yang perpaduannya jarang ditemukan pada budaya lain.

\section{METODE}

Pendekatan Kualitatif dalam penelitian ini digunakan untuk studi fenomenologi. Wawancara mendalam secara semi struktur digunakan pada 10 orang Informan selama bulan Januari-Maret 2017, yang dipilih secara purposive dengan kriteria: Pengguna Puree aktif dengan motif ingin berhenti merokok dan sebelumnya pernah menjadi perokok aktif yang berasal dari Kecamatan Angata. Disamping itu, 2 orang informan diambil dari pejabat pemerintah setempat di Kecamatan Angata, untuk menguatkan keterangan tentang asal mula pengguna Ramuan Puree serta kecenderugan penggunaannya.

Wawancara yang sebelumnya diatur mengambil waktu antara 70 sampai 90 menit. Pada umumnya seluruh wawancara direkam dengan alat perekam dengan menggunakan Bahasa Indonesia, kemudian ditranskrip kata demi kata dan di artikan kedalam Bahasa Inggris. Pertanyaan yang digunakan berasal dari beberapa isu yang muncul dalam upaya berhenti merokok warga Angata terkait penggunaan ramuan Puree.

Kontak kami dengan sejumlah besar pengguna dalam konteks penggunaan "Puree" sebagai upaya menghentikan kebiasaan merokok memungkinkan kita untuk secara sistematis dan penuh perhatian mengikuti fakta-fakta dalam rangka untuk menarik dan memasukkan data mengenai efektifitas ramuan ini dan melihat bagaimana perspektif masyarakat.

Keuntungan dari wawancara tatap muka, dibandingkan dengan metode lain dari penelitian seperti observasi, eksperimen, analisis dokumen, atau kuesioner, adalah bahwa orang yang diwawancarai memberikan perhatian yang lebih besar dan memberikan jawaban yang lebih tepat. Dalam rangka untuk mendapatkan jawaban valid, kami berikan garansi kerahasiaan kepada Pengguna aktif yang kami wawancarai dan kami memberikan keyakinan bahwa pertanyaan yang tidak dianggap mengganggu dari sudut pandang sosial maka dapat dipromosikan dalam masyarakat.

Pada pengamatan sebelumnya, kontak langsung dengan budaya setempat terkait ramuan ini yang fokuskan di desa Aopa dan Kosebo, karena menurut informasi awal kedua desa ini memiliki banyak pengguna Puree Aktif dan masih mempraktekkan kebiasaan ini, bahkan sampai pengguna pada wanita dan anak usia dibawah 15 tahun, meskipun tidak dengan motif untuk menghentikan kebiasaan merokok.
Terhadap 10 Pengguna aktif yang diwawancarai, seluruhnya adalah laki-laki yang menggunakan Puree minimal diatas 2 tahun lamanya. Pemilihan pengamatan pada pria, karena pada warga Angata hampir tidak ditemukan selama pengamatan perokok wanita dan anak-anak, sehingga pengamatan fokus pada upaya menghentikan kebiasaan merokok pada pria dengan ramuan Puree.

Wawancara dengan informan kemudian di kodesasi dan dikategorisasi dan dialakukan beberapa kali untuk membuat system klasifikasi tematik ${ }^{9}$. Proses validasi teoritis dilakukan untuk memastikan bahwa klasifikasi unit (tema, isu, dan konsep) sensitif dan bersesuaian dengan narasi informan ${ }^{10}$. Langkah yang dilakukan adalah kembali memastikan langsung ke informan melalui wawancara singkat bahwa informasi yang telah diambil sebelumnya sesuai dengan narasi sebelumnya.

3 langkah dari analisis tematik dilaksanakan. Pertama, tema yang diekstrak dari transkrip, kedua tema ini kemudian dikategorisasi dan diorganisasi, dan akhirnya analisis interpretasi menghasilkan sebuah penjelasan teoritis dari konteks social dari penggunaan ramuan Puree sebagai upaya untuk menghentikan kebiasaan merokok.

\section{HASIL DAN PEMBAHASAN}

Karakteristik Partisipan

Partisipan dalam penelitian ini sebanyak 10 orang; 8 berjenis kelamin laki-laki dan dua orang berjenis kelamin perempuan yang berusia dalam rentang 20 sampai 65 tahun. Tingkat pendidikan partisipan bervariasi mulai dari pendidikan SD sampai PT. Partisipan dalam penelitian ini adalah pengguna aktif ramuan Puree berasal dari warga Kec. Angata. 2 Orang adalah Tokoh Masyarakat dan Kepala Desa, serta yang lainnya adalah warga biasa. Agama yang dianut oleh semua partisipan adalah agama Islam.

Kita mulai dengan diskusi singkat tentang konteks sosial penggunaan Ramuan tradisional Puree pada masyarakat Angata sebagai salah satu kearifan lokal warganya, serta mencoba menekankan pada efektifitasnya dalam upaya menghentikan kebiasaan merokok pada pria disana.

\section{Konteks Sosial}

Tingginya populasi perokok aktif di Sulawesi Tenggara terlihat dari hasil Riset Kesehatan Dasar dengan besaran persentase perokok aktif sebesar 21,8 persen dari jumlah penduduknya. Data ini menggambarkan begitu tingginya populasi perokok aktif yang ada di Indonesia, khususnya di Sulawesi Tenggara, terlebih perokok pada pria masih sangat 
dominan ${ }^{2}$. Sedangkan jika dilihat dari pengeluaran untuk kesehatan dari total pengeluaran sebulan di Indonesia hanya sebesar 3,29\%. Persentase rata-rata pengeluaran kesehatan tersebut masih lebih kecil jika dibandingkan dengan kebutuhan terhadap pengeluaran untuk tembakau dan sirih sebesar $6,33 \%{ }^{11}$

Namun, dibalik hal tersebut ternyata peran tenaga kesehatan dalam mempromosikan dampak buruk dari rokok perlu memfokuskan pada penguatan aspek individu. Telah banyak kasus penyakit akibat rokok dan pengalaman pribadi perokok terhadap dampak negatif merokok memberikan efek jera, sehingga tak jarang mereka berupaya mencari cara untuk menghentikan kebiasaannya itu ${ }^{12}$.

Pada Masyarakat Kecamatan Angata, Kabupaten Konawe Selatan, Provinsi Sulawesi Tenggara memiliki salah satu kearifan lokal untuk menghentikan kebiasaan merokok, yang secara turun-temurun dipraktikkan oleh warga setempat yakni menggunakan ramuan yang disebut "Puree".

"..iye. kalau kt disini ini mepuree [menggunakan puree] sdh kebiasaan dari nene ne ne ta dulu.." (Informan PG).

"..disini juga, kalau ada acara biasami itu di jaidkan sajian juga untuk tamu (Informan BP).

Puree adalah ramuan yang diracik dari tembakau (yang bertekstur padat dan basah) yang diberi tetesan air putih kemudian di campurkan dengan kapur sirih yang terbuat dari kulit kerang yang dibakar dan diabukan dengan takaran sesuai dengan selera dan kebutuhan penggunanya.

"..cara buatnya itu [pure], dari tembakau 77 khusus dia itu untuk mepuree, dikasi air sedikit, baru dicamur dengan abu dari bakar kulit pokea atau kulit kerang, kt sebut kapur sirih.."(Informan MR)

Setelah di lakukan penelusuran ternyata kebiasaan ini Kurang popular pada daerah lainnya, bahkan cenderung tidak diketahui.

" kalau mepure itu saya tidak tau kalau ada di tempat lain orang pake, kayanya tidak ada, kalaupun ada, paling orang siniji yang ajarkan atau bawa keluar" (Informan MR)

Masyarakat Angata sendiri percaya bahwa resep dari leluhur mereka ini merupakan salah satu cara efektif dalam mengatasi kebiasaan merokok.

"disini toh, ada juga yang bisa berhenti merokok gara-gara mepure ji" (Informan KD).

"..saya dulu perokok tulen, tapi akrena sa habis sakit batuk parah masuk rumah sakit, akhirnya sa tobatmi merokok, akhirnya saya dikasi tau pake terus pure, ee langsung sa jijik itu liat rokok gara-gara mepure .." (Informan PG).
Namun, dalam pengamatan yang dilakukan terungkap bahwa, Puree tidak hanya digunakan sebagai subtitusi rokok tetapi dalam beberapa kasus diketahui bahwa ada juga pengguna Puree dengan latar belakang bukan perokok, yakni pada wanita dan anak-anak usia 10-15 tahun.

"..mm, disini bukan hanya laki-laki pake pure, banyak juga perempuan, malah ada anak-anak, mereka biasa pake karena coba-coba saja, atau perempuan kasi merah bibirnya" (Informan NN)

\section{Inisiasi Puree sebagai Upaya Berhenti Merokok}

Ramuan Puree merupakan ramuan yang diracik dari tembakau yang diberi tetesan air putih kemudian di campurkan dengan kapur sirih yang terbuat dari kulit kerang yang dibakar dan diabukan dengan takaran sesuai dengan selera dan kebutuhan penggunanya, serta berwarna hitam dan berbentuk pasta. Penggunaannya adalah dengan dioleskan pada bibir tanpa ditelan. Bau yang timbul dari perpaduan bahannya yang kemudian dihirup melalui hidung dan memberikan sensasi tersendiri bagi penggunanya.

"meracik pure itu sesuai selera ji, ndada ji takarannya, mau-mauta saja, Cuma kalau sdh ketergantunganmi biasanya olesan di bibir nya ditambah, bukan hanya dibawah, tapi diatas juga" (Informan MR)

"tembakaunya itu khusus, bukan untuk rokok, agak basah dia, namanya tembakau 77 sengaja dijual di toko ini" ( Informan PT)

[hasil pengamatan peneliti, terlihat beberapa warga menggunakan pure dengan cara mengoleskan campuran bahan kapur sirih dan air tembakau sampai berbentuk pasta dan dioleskan kebibir, ada yang sedikit, ada pula yang seluruh bagian bibir, tetapi tidak sampai masuk ke oral]

Penggunaan ramuan Puree pada awalnya merupakan kebiasaan para leluhur masyarakat Angata. Kebiasaan masyarakat Angata pada setiap penyelenggaraan acara pernikahan ataupun pesta rakyat, maaupun menerima tamu, biasa menyajikan ramuan ini, bersamaan atau tidak dengan rokok, dikarenakan lebih banyaknya pengguna Puree dibandingkan perokok disana.

"..disini kayaknya lebih banyak yang mepuree pak dari pada merokok.." (Informan CW).

Jika pada rokok, inisiasinya disebabkan karena merokok sangat terkait dengan teman-teman dekat mereka yang merokok ${ }^{7}$, serta faktor lingkungan sosial karena keinginan untuk mendapatkan pengakuan menemukan hal menarik-seperti ketangguhan, keseksian, dan pemberontakan ${ }^{13}$, lain halnya dengan Ramuan Puree. Inisiasi pengguna Puree pada umumnya bermotif pada 
keinginan untuk menghentikan kebiasaan merokok, yang menurut mereka sangat efektif dalam upaya berhenti merokok dan tidak ada pola motif yang sama ditemukan untuk mendapat pengakuan dari lingkungan sosial untuk terkesan jantan/keren seperti pada perilaku merokok.

"..disini mepuree kan kebiasaan orang tua dulu, dulu. Banyak yang coba pake puree itu biasanya Karena dulu merokok dan mau berhenti...pake puree ini bisa kasi tawar rasanya rokok kalau sering di pake.." (Informan BP).

Informan mulai menggunakan Puree karena menginginkan sesuatu yang berbeda dari rokok. Rokok dipandang berbahaya karena mengeluarkan asap dimana persepsi mereka bahwa asap tersebutlah yang berbahaya bagi kesehatan tubuh utamanya paru-paru.

“.rokok diakan berasap, bikin sakit paru-paru, kalau mepuree dia tidak ada asapnya, jadi kayaknya aman untuk paru-paru.." (Informan $\mathrm{MR}$ )

Puree dianggap lebih aman dikarenakan tidak menghasilkan asap sehingga dipersepsikan baik bagi mereka. Dalam pengamatan diketahui bahwa seluruh informan menyatakan puas dengan hasil dari menginisiasi Puree dan memutuskan untuk mempertahankan kebiasaan ini untuk menekan hasrat ingin merokok.

Dampak awal inisisasi yang dirasakan informan terungkap bahwa timbul efek yang dirasakan sangat mengganggu yakni : Pusing, mual dan pada beberapa kasus sampai muntah, serta rasa ingin buang air besar secara spontan.

"..Pertama kali pake pangsung mencret [diare, tapi bagusnya dia kasi lancer BAB" (Informan PG)

"ada yang pertama pake langsung pusing, bahkan pingsan" (Informan MR)

Namun efek ini hanya dirasakan pada awal menginisiasi ramuan ini. Dikatakan setelah menggunakan selama beberapa kali, maka efek ini perlahan-lahan dapat ditoleransi bahkan menghilang.

“..awal-awalji kita rasa ousing, mual, atau sakit perut, lama-lama biasami.." (Informan ASP).

Namun, juga terlihat dalam pengamatan, bahwa efek samping tersebut dapat hadir kembali -[[]=[[-j wrnpada saat pengguna berada dalam kondisi tidak prima saat menggunakannya.

“..kadang kalau tidak enak badanku, baru pake puree biasanya sa [saya] oleng.." (Informan $\mathrm{BP})$.

Namun diungkap pula, efek samping ini dapat segera diatasi dengan cara membasuh sampai bersih jejak ramuan Puree pada bibir dan wajah, serta mengkonsumsi air putih. $\begin{array}{ccc}\text { Setelah menginisiasi ramuan ini, pada } & \begin{array}{c}\text { medran } \\ \text { umumnya }\end{array}\end{array}$ kebiasaannya. Perasaan yang berbeda yang dirasakan dibandingkan dengan pada saat mereka masih aktif merokok turut menyumbang peran berlanjutnya pengguna dari inisiasi menjadi pengguna aktif.

"..karena kita sdh rasa efeknya bagus, bisa berhenti merokok, bahkan tambah semangat olahraga.." (Informan PG)

"..ndadaji saya rasa apa-apa, malah tambah semangat kalau pake.." (Informan BP)

Terlihat bahwa rata-rata informan yang menggunakan Puree lebih dari 2 tahun lamanya menggunakan ramuan oles ini minimal 5 kali dalam sehari dalam beberapa kasus bahkan lebih.

Tidak ada waktu tetap yang disarankan oleh pengguna aktif Puree untuk menggunakan Puree. Hanya jika keingingan untuk menggunakannya datang, maka apabila bahannya tersedia, mereka pun secara langsung menggunakannya. Tetapi, apabila bahannya tidak tersedia, pada umumnya mereka menyatakan tidak merasa kehilangan/mendapatkan keinginan besar untuk segera menggunakannya.

Salah satu penyebab cukup rendahnya ketergantungan pada ramuan ini karena ramuan Puree kurang praktis untuk dibawa kemana saja, sehingga dirasakan cukup merepotkan dalam penggunaannya.

"..repot juga kalau mau bawa-bawa terus kemana saja, malu-malu juga dilihat orang, kalau rokok kan gampang.." (Informan ASP)

Diketahui pula bahwa, beberapa responden terlihat canggung untuk tampil dimuka umum/terlihat oleh orang banyak sewaktu mengoleskan Puree pada bagian bibir, salah satu penyebabnya karena kurang nyaman secara estetika, karena warna hitam ramuan ini yang dioleskan dibibir, menyebabkan mereka kurang nyaman menjadi perhatian orang.

".sa nda pede dilihat kalau pake puree.." (Informan MR)

Dari 10 orang informan yang diwawancarai, menyatakan waktu paling ideal menggunakan Puree adalah setelah makan dan diwaktu bangun pagi.

"..uuh paling enak itu pagi habis makan, kaya orang merokok itu.." (Informan AMD)

Hal ini memiliki pola yang sama dengan perilaku merokok, dimana pada saat-saat inilah nikmatnya merokok juga paling dinikmati pengguna aktifnya ${ }^{14}$. Ketika ditanyakan apakah Puree dapat memberikan rasa hangat pada saat menggunakannya, mereka menyampaikan tidak 
ada rasa seperti yang didapatkan ketika konsumsi rokok pada saat cuaca dingin.

"..bedanya, kalau puree kan tidak bisa kasi hangat tubuh.. (Informan KD)

\section{Efektifitas Penggunaan Ramuan Puree dalam Menghentikan Kebiasaan Merokok}

Penting untuk dicatat bahwa pengguna aktif Puree bukan tanpa efek adiksi/dependensi. Dalam hasil wawancara diungkap bahwa pengguna Puree mempertahankan kebiasaan ini juga merasakan adanya rasa yang datang untuk kembali menggunakan pada saat-saat tertentu. Tetapi setelah dikonfirmasi, adiksi yang dirasakan untuk menggunakan kembali Puree secara terus-menerus tidak seberat saat mereka masih aktif sebagai perokok.

"..ah agak ketergantungan juga, tapi nda kaya rokok ji dia ini, kapan saja kalau sa disuruh berhenti gampang sa lepas.." (Informan PG)

Terungkap dalam wawancara, penggunaan Puree lebih mudah dilepaskan/ditinggalkan dibandingkan merokok ${ }^{15}$.

Terjawab juga dalam wawancara mendalam, bahwa efektifitas ramuan Puree ini dalam menekan hasrat ingin merokok diakui berhasil. Keseluruhan informan menggambarkan bahwa setelah mempertahankan penggunaan Puree selang beberapa waktu (lebih dari 5 kali dan aktif setiap hari) dapat membuat rasa rokok menjadi hambar/tawar, bahkan salah seorang informan mengkonfirmasi merasakan mual dan jijik ketika bersentuhan dengan rokok maupun asap rokok.

Rasa hambar pada rokok yang dirasakan setelah secara aktif menggunakan ramuan Puree, merupakan faktor yang sangat efektif sampai akhirnya seluruh informan menyatakan tidak pernah lagi merokok.

“..saya berhenti totalmi merokok, gara-gara mepuree.." (Informan PG)

Belum ditemukan selama pengamatan adanya informan yang aktif menggunakan Puree masih berstatus sebagai perokok aktif. Temuan ini mengkonfirmasi bahwa Puree secara efektif dapat menurunkan secara signifikan keinginan untuk merokok, bahkan melepaskan perilaku merokok secara permanen.

Hal diatas bersesuaian dengan keterangan informasi dari pejabat pemerintah setempat yang diwawancarai, dan memberikan keterangan bahwa diakui bahwa Puree telah memiliki reputasi turun temurun sebagai ramuan tradisional yang khas di praktekkan warga Angata untuk menghentikan kebiasaan merokok.

Dampak lain yang ditemukan pada informan yakni respon spontanitas terhadap keinginan buang besar, sehingga menurut pendapat penggunanya, penggunaan Puree juga dapat memperlancar buang air besar dipagi hari ketiga menggunakannya.

\section{Tingkat Ketergantungan}

Pada beberapa informan yang diamati menyatakan bahwa tingkat adiksi yang dirasakan ada meskipun dalam kondisi dapat dikendalikan.

"..ketergantungan ada juga kalau puree, hanya bisa ji di atur dia.." (Informan ASP)

Hal berbeda dirasakan ketika masih aktif sebagai perokok, dimana adiksi untuk merokok memberikan peran yang sangat besar sehingga sangat sulit untuk dilepaskan. Sehingga dipastikan oleh informan bahwa mereka akan lebih mudah melepaskan penggunaan ramuan Puree jika diminta dibandingkan melepaskan perilaku merokok.

Dari pernyataan diatas dapat dipahami bahwa tingkat ketergantungan pengguna Puree masih dalam batas bisa terkontrol oleh penggunanya. Keinginan untuk tetap menggunakannya dikarenakan perasaan aman bagi kesehatan, serta belum adanya larangan terkait kesehatan dalam penggunaan Puree, sehingga dipersepsikan baik bagi mereka, selain itu kebiasaan turun-turun dan banyaknya pengguna disekitar mereka serta mudah dan murahnya bahan-bahan meracik ramuan ini semakin menguatkan keinginan mereka untuk terus menggunakan Puree.

Meskipun Puree bukan merupakan olahan tembakau seperti suntil yang dimasukkan ke dalam mulut dan diletakkan di sudut mulut kanan atau kiri, serta tidak terbentuk adanya asap, tetapi kadar nikotin yang dijumpai dapat melampaui ambang batas seperti pada suntil (tembakau kunyah) sehingga dapat menimbulkan ketagihan. Pada Suntil tidak mengandung tar karena tar hanya dijumpai apabila tembakau dibakar ${ }^{8}$, begitu pula dengan ramuan Puree yang masuk lewat pernafasan penggunaanya.

Untuk mengkaji lebih jauh level adiksi/ketergantungan yang ditimbulkan ramuan Puree, perlu dilakukan uji laboratorium lebih lanjut. Selain itu dapat dipastikan bahwa bahan pembuatan ramuan Puree yakni tembakau dapat menyumbang masukan nikotin kedalam tubuh melalui pernafasan. Sehingga Puree tidak disarankan untuk digunakan secara terus menerus setelah upaya berhenti merokok telah tercapai (total berhenti merokok).

Dikhawatirkan jika Puree dapat menyumbang faktor resiko pada penyakit yang disebabkan bahan karsinogenik dalam memicu penyakit kanker, jika digunakan dalam waktu yang lama dan frekuensi 
yang banyak, karena tetap dapat menimbulkan tumpukan nikotin dalam darah. Meskipun ada motif lain penggunaan Puree selain untuk upaya berhenti merokok yang di identifikasi dalam penelitian ini, dan hal tersebut juga perlu dikonfirmasi dengan penelitian selanjutnya.

\section{SIMPULAN DAN SARAN}

Telah dibahas dalam tulisan ini, bahwa Penggunaan ramuan Pure efektif dalam upaya untuk berhenti merokok, dengan menekan dan memberikan sensasi lain dan berbeda dengan merokok, sehingga perokok aktif mampu melepaskan kebiasaan merokok.

Fenomena penggunaan pure sebagai salah satu cara yang paling disarankan masyarakat Angata sebagai warisan turun temurun mereka untuk menghentikan kebiasaan merokok telah mendapat reputasi yang sangat baik. Hal ini terlihat pada pengguna pure pada perokok aktif yang kemudian secara total menghentikan kebiasaannya dalam menkonsumsi rokok.

Pada umumnya, inisiasi pure pada pria perokok di Angata dimulai ketika merasakan dampak buruk merokok bagi kesehatannya. Efektifitasnya dalam membuat merokok menjadi sangat tidak diinginkan lagi, yakni rokok terasa hambar dan terkadang membuat mereka jijik setelah menggunakan pure selang beberapa waktu.

Terdapat beberapa keterbatasan dalam penelitian ini. Ketika membuat penilaian keuntungan yang diperoleh dengan beralih dari merokok kemudian menggunakan tembakau tanpa asap seperti ramuan pure ini, maka diperlukan penelitian dan data tentang pengurangan risiko melalui studi di kohort jangka panjang untuk tindak lanjut kepada mantan perokok yang menghentikan kebiasaan merokok dengan menggunakan ramuan pure.

\section{DAFTAR PUSTAKA}

1. U.S. Department of Health and Human Services. How Tobacco Smoke Causes Disease: The Biology and Behavioral Basis for Smoking-Attributable Disease: A Report of the Surgeon General. Rockville, MD; 2015.

2. Kementerian Kesehatan Republik Indonesia. Riset Kesehatan Dasar 2013. Jakarta; 2013.

3. Carreras G, Gallus S, lannucci L, Gorini G. Estimating the probabilities of making a smoking quit attempt in Italy: Stall in smoking cessation levels, 1986-2009. BMC Public Health [Internet]. 2012;12(1):183. Available from:

http://www.biomedcentral.com/1471-2458/12 $/ 183$

4. World Health Organization. Noncommunicable disease country profiles 2011 WHO global report,. Geneva, Swiss; 2013.

5. Firzawati. Faktor Upaya Berhenti Merokok pada Perokok Aktif Umur 15 Tahun Keatas di Indonesia. University of Indonesia; 2015.

6. Benowitz NL, Brunetta PG. Smoking Hazards and Cessation. In: Mason RJ, Murray JF, Broaddus VC, 1. Nadel JA. Edition editors. M and NT of RM 4th, editor. Philadelphia; 2005.

7. Nilsson R. De Minimus non Curat Lex - Virtual Thresholds for Cancer Initiation By Tobacco Specific Nitrosamines - Prospects for Harm Reduction by Smokeless Tobacco. Int J od accupational Med environtmental Heal. 2006;19(1):6-35.

8. Sitepoe M. Kekhususan Rokok Indonesia. Jakarta: PT. Gramedia Widiasarana Indonesia; 2000.

9. Green J, Thorogood N. Qualitatif Methods in Helath Research. Thousand Oaks, California: Sage Publication; 2004.

10. Glasser BG, Strauss AG. The Discovery of Grounded Theory: Strategies for Qualitatif Research. New York: Aldine; 1967.

11. Kementerian Kesehatan Republik Indonesia. Profil Kesehatan Indonesia Tahun 2015. Jakarta; 2015.

12. Dalton MA, Sargent JD, Beach $M L$, Titus-Ernstoff L, Gibson JJ, Ahrens MB, et al. Effect of viewing smoking in movies on adolescent smoking initiation: A cohort study. Lancet. 2003;362(9380):281-5.

13. Tjora T, Hetland J, Aarø L, Verland S. Distal and proximal family predictors of adolescents' smoking initiation and development: A longitudinal latent curve model analysis. BMC Public Health [Internet]. 2011;11(1):911. Available from: http://www.biomedcentral.com/1471-2458/11 $/ 911$

14. Perkins KA. Metabolic effects of cigarette smoking. J Appl Physiol. 1992;72(2):401-9.

15. Pazarli Bostan P, Karaman Demir C, Elbek O, Akçay Ş. Association between pulmonologists' tobacco use and their effort in promoting smoking cessation in Turkey: A cross-sectional study. BMC Pulm Med. 2015;15(1):1-7. 